\title{
Immunologic Factors in Patients with Chronic Polypoid Sinusitis
}

\section{**Nikakhlagh S MD *\# Ghafourian-Boroujerdnia M PHD, Saki N MD *? Soltan-Moradi M R MD; Rahim F, M.SC}

* Department of Otolaryngology, Head and Neck Surgery, Ahwaz Jondishapour University of Medical Sciences, Ahwaz, Iran. ?Department of Immunology, Medical Faculty, Ahwaz Jondishapour University of Medical Sciences, Ahwaz, Iran. " Apadana Clinical Research Center, Apadana hospital, Ahwaz, Iran. ${ }^{*}$ Departments of ENT, Imam Hospital, Ahwaz Jondishapour University of Medical Sciences, Ahwaz, Iran

\begin{abstract}
Background: Nasal polyposis is the benign protrusion of soft tissue into the nasal cavity, with multifactorial origin. This study is designed to examine the suggested role of $\lg \mathrm{E}$ and $C D_{4}$ and $C D_{8}$ lymphocytes in the pathogenesis of nasalpolyposis.

Method: Blood samples were taken from 32 patients with chronic polypoid sinusitis and 32 controls. $C D_{4}$ and $C D_{8}$ total lymphocyte count were determined by flow cytometry and the level of serum IgE was measured by ELISA. Nasal discharge samples were also collected for determining IgE level in both patients and controls during surgery.
\end{abstract}

Results: In $68.8 \%$ of patients a history of allergy was present. The level of nasal discharge lgE was significantly higher $(p<0.001)$ in patients compared to controls, but the difference between serum IgE levels was not significant $(p>0.05) . C D_{8}$ concentration and blood lymphocytes were significantly higher $(p<0.001)$ in the patients group, while $C D_{4}$ concentration was significantly lower $(p<0.001)$ in them. Finally, $C D_{4} / C D_{8}$ ratio was significantly lower $(p<0.001)$ in the patients group.

Conclusion: This study suggests that a change in the amount of $C D_{4}$ and $C D_{8}$ lymphocytes and an increased level of local $\lg E$ contribute to nasal polyposis, but the results should be confirmed in more extensive studies including cytokine analyses. Such increasing insights in the pathophysiology of nasal polyposis open perspectives for new pharmacological treatment options, with immunologic factors as potential targets.

Keywords: Nasal polyposis, $C D_{4}, C D_{8}, \lg E$

\section{Date Accepted for publication: 18th July 2007 \\ Nig J Med 2009; 380 - 383 \\ Copyright $@ 2009$ Nigerian Journal of Medicine}

\section{Introduction}

The history of nasal polyps dates back to over three thousand years ago in India, where a type of curette was described for eradicating nasal polyps. ${ }^{1}$ Nasal polyps are seen in patients of all ages. They are present in approximately $2 \%$ of the general population. There is at least a 2:1 male to female predominance. ${ }^{1}$ The frequency of nasal polyps increases with age, reaching a peak in individuals 50 years and older. Nasal polyposis is not a disease, but a physical finding with a number of causes and associated conditions. ${ }^{2}$ Most commonly, $25 \%-30 \%$ of patients have asthma, while approximately $12 \%$ have aspirin intolerance. Nasal polyps are also seen in $0.1 \%$ of children and $20 \%$ of patients with cystic fibrosis. They are seen in $50 \%$ of patients with eosinophilic vasculitis of Churg Strauss syndrome. They are also seen in disorders of ciliary motility like Kartagener's syndrome, as well as other genetic syndromes such as Young's syndrome, which is a bronchopulmonary disease accompanied by azoospermia. $^{3}$

Proposed mechanisms implicated in the development of nasal polyps include: allergy, infection, autonomic imbalance, mucopolysaccharide abnormalities, enzyme abnormalities, drug sensitivity and mechanical obstructions.

Nasal polyps consist of respiratory epithelium covering a very edematous stroma infiltrated by a large number of inflammatory cells with eosinophils being the predominant group. ${ }^{1}$ Bilateral nasal polyposis is associated with concentrations of $\mathrm{lgE}$ in nasal polyp tissue. Infiltrated mast cells demonstrate ultra structural signs of degranulation, associate with continuous release of histamine, which is found in higher concentrations in polyp fluid. ${ }^{2}$

The presence of controversies in previous studies that evaluated the lymphocyte subpopulations and their production of cytokines and $\mathrm{lg} E$ in serum and nasal secretion in order to elucidate the role of immunologic factors in the process of nasal polyps as well as difference in their results lead us to do further investigations. ${ }^{5-10}$ So in this sequel, this study is designed to examine the suggested role of $\lg \mathrm{E}$, and $\mathrm{CD}_{4}$ and $\mathrm{CD}_{8}$ lymphocytes in the pathogenesis of nasal polyposis. 


\section{Patients and Methods}

Seventeen men and 15 women, ranging in age from 20 to 71 years (mean, 46.6 years), who had chronic rhinosinusitis with diffuse nasal polyps and underwent endoscopic sinus surgery, were included in this study. All of the patients gave written informed consent and the study was approved by the Institutional Review Board and ethics committee of Ahwaz Jondishapour University of Medical Sciences. The demographic data of the study and control groups have been given in the Table I. The Peripheral blood samples were taken from 32 patients for whom the diagnosis of chronic polypoid sinusitis was established, and 32 control patients who were candidates for septoplasty who had a negative history of allergy and sinusitis. The samples were sent to laboratory for lymphocyte count and determination of amounts of $\mathrm{CD}_{4}$ and $\mathrm{CD}_{8}$ lymphocytes by flow cytometry (Becton Dickinson Co., USA), and serum IgE by ELISA. Nasal discharge samples were also collected for determining local lgE level in both patients and controls during surgery.

Monoclonal antibodies used in flow cytometry analysis included fluorescein isothiocynate (FITC) and phycoerythrin $(\mathrm{PE})$-conjugated against $\mathrm{CD}_{4}$ and $\mathrm{CD}_{8}$ markers (Dako Co., Danmark). All samples were washed in sodium perborate (PBS) after staining procedures, followed by exposure to a lysing reagent again. FITC and $\mathrm{PE}$-conjugated mouse lgG1 were incubated with cells obtained from Patients in parallel to negative controls. Prepared immunostaining cell suspensions were submitted to flow cytometry analysis. IgE levels were measured in serum and nasal discharge samples using a kit prepared from PAD TANELAM Company of Iran, and were recorded based on international units per milliliter $(\mathrm{IU} / \mathrm{ml})$.

Statistical analysis: The data obtained were analyzed statistically using the t-test. P-values less than 0.05 were considered as significant.

\section{Results}

IgE level of nasal discharge was significantly higher $(p<0.001)$ in patients compared to the control group; it was $84.6 \mathrm{IU} / \mathrm{ml}$ in the patients group $20.9 \mathrm{IU} / \mathrm{ml}$ in the control group. Also the difference in serum IgE was not significant $(p>0.05)$ with a values of $130.5 \mathrm{IU} / \mathrm{ml}$ in Patients and $127.6 \mathrm{IU} / \mathrm{ml}$ in controls (Table II). In 68.8\% of patients a history of allergy was present. CD8 concentration (46.8\% in patients vs $28.3 \%$ in controls) and percentage of peripheral blood lymphocytes $(17.7 \%$ in Patients and $31.6 \%$ in controls) were significantly different ( $p<0.001$ for both comparisons) between the two groups (Table II). Ironically, CD4 concentration was significantly lower $(p<0.001)$ in patients (Table II). Finally, $C D 4 / C D 8$ ratio was significantly lower $(p<0.001)$ in the patients (Table II).

Table I: Demographic and immunological features of patients and control groups

\begin{tabular}{|l|c|c|c|}
\hline Variables & Patients $(\mathrm{n}=32)$ & Control $(\mathrm{n}=32)$ & P-Value \\
\hline Median age (year) & 53 & 46 & 0.341 \\
\hline Gender (Male: Female) & $15: 17$ & $13: 19$ & 1.0 \\
\hline Elevated serum IgE (frequency) & $22(68.75 \%)$ & $3(9.37 \%)$ & 0.001 \\
\hline Blood eosinophilia & $27(84.37 \%)$ & $2(6.25 \%)$ & 0.001 \\
\hline Lymphocytes (Mean \pm SD) & $31.69 \pm 7.97$ & $17.72 \pm 5.84$ & 0.05 \\
\hline
\end{tabular}

Table II: difference in variables between patients and control groups

\begin{tabular}{|c|c|c|c|}
\hline Variables & $\begin{array}{l}\text { Patients group }(n=32) \\
\text { (Mean BS }\end{array}$ & $\begin{array}{l}\text { Control group }(n=32) \\
\quad \text { (Mean } \mathbb{A S}\end{array}$ & P-value \\
\hline $\begin{array}{l}\text { IgE level of nasal discharge } \\
(|\mathrm{U} / \mathrm{m}|)\end{array}$ & 84.69 & 20.91 & 0.001 \\
\hline Serum IgE (IU/ml) & $130.558 \pm$ & 127.628 & 0.92 \\
\hline CD8 concentration (\%) & $46.88 \mathrm{z \pm}$ & $28.36 * 1$ & 0.001 \\
\hline $\begin{array}{l}\text { Percentage of peripheral blood lymphocytes } \\
(\%)\end{array}$ & $17.72 \mathrm{g \pm}$ & $31.698 \pm$ & 0.001 \\
\hline CD4 concentration (\%) & $38.250 \pm$ & 53.83 & 0.001 \\
\hline CD4/CD8 ratio & 0.8409 & $1.9897 \theta \pm$ & 0.001 \\
\hline
\end{tabular}

\section{Discussion}

Although the etiology of nasal polyposis is still not revealed, insights in the pathogenesis have largely expanded over the last years. ${ }^{11}$ There are two models suggested for the development of nasal polyposis: one states that this condition is caused by the up-regulation of cytokines leading to increased eosinophil degranulation; the other mechanism suggests that injury to the airway epithelial cells induced by an allergen, viruses or trauma leads to defective transmembrane regulators, which in turns alters sodium chloride flux in the epithelial cell and finally directs to edema. $^{3}$

A consistent feature in nasal polyposis is a prominent infiltration of inflammatory cells, and it has been proposed that alteration of immune regulation could be implicated as a contributing factor. The eosinophil leukocyte is the dominant cell in polyps; consequently, allergy has been considered as an important etiology for nasal polyps. ${ }^{4}$

The prevalence of allergy in patients with nasal polyps varies from $10 \%$ to $54 \%$. There is a coincidence of asthma and nasal polyps but the association between polyposis and atopic conditions is not clear. It has been newly suggested that Staphylococcus Aureus may have a role in formation of nasal polyps. This pathogen 
is found in the nasal samples obtained from these patients, although the significance is unclear. The bacteria may secrete exotoxins that act as superantigens and are a possible trigger for local $\mathrm{lgE}$ production in nasal polyposis. ${ }^{11-13}$

It should be emphasized that the presence of eosinophils in the polyps does not depend on the presence of allergy or lgE-mediated hypersensitivity disorders, but is related to up-regulation of appropriate cytokines and growth factors such as interleukin-1â, tumor necrosis factor, macrophage colony stimulating factor. ${ }^{14}$ All these cytokines have direct or indirect effects on the transmigration of eosinophils from the microvasculature into the lamina propria of nasal polyps. In one study, Benrstein et al. showed that two subpopulations of lymphocytes, $C D_{4}$ and $C D_{8}$, have significant roles in production of these cytokines. Their findings imply that there are significant differences between the percentage of lymphocytes producing these cytokines in nasal polyps and peripheral blood. Lymphocytes infiltrated in nasal polyps may derive from a source other than peripheral blood. ${ }^{2,15}$ They may be derived from both the local mucosal immune system as well as from random migration of peripheral blood lymphocytes. ${ }^{15,16}$

Ihan and Suskovic evaluated $C_{4}$ and $C D_{8}$ cells isolated from nasal tissue in allergic and nonallergic polypoid patients, and found a significant increased expression of intercellular adhesion molecule-1 (ICAM-1) molecules on $\mathrm{CD}_{8}$ cells in nonallergic compared to allergic patients. This finding may reflect the difference in cytotoxic immune response between allergic and nonallergic patients, ${ }^{16}$ although it is inconsistent with the result of a study by $\mathrm{Hel}$, in which the expression percentage of $\mathrm{CD}_{3+}, \mathrm{CD}_{4^{+}}$ cells appeared to be significantly higher than that of $\mathrm{CD}_{3+}, \mathrm{CD}_{8+}$ cells. $^{13,17}$

A survey conducted by Muluk implies on the role of Thelper lymphocytes in the pathophysiology of chronic sinusitis, and $\mathrm{CD}_{4+}$ T-helper cells in particular are thought to be predominant at the initiation and regulation of inflammation. ${ }^{14,18}$

Our study shows that a change in the amount of $\mathrm{CD}_{4}$ and $\mathrm{CD}_{8}$ lymphocytes and an increase in the level of local lgE to be important, which suggests that local allergy may play a key role in sinonasal polyposis; however, the results should be confirmed in more extensive studies which recruit cytokine analysis. Increasing insights in the pathophysiology of nasal polyps let us gain open perspectives for new pharmacological options with $C_{4}$ and $\mathrm{CD}_{8}$ lymphocytes and local $\lg \mathrm{E}$ secretion as potential targets for treatment. We hope that it would enable us to obtain a deeper insight into the local immune events and further to clarify the etiology and pathogenesis of nasal polyps and their relation to allergy.

\section{Acknowledgements}

The authors would like to thank Farzan Institute for Research and Technology for technical assistance.

\section{References}

1. Raymond G, Salvin L. Nasal polyp and sinusitis. Middleton JR, Reed CE, Elliot EF, et al, eds. Allergy principles and practice. 5th ed. St Louis: Mosby Year Book Inc; 1998.pp. 393-403

2. Bachert $C$, Gevaert $P$, Holtappels $G$, Van Cauwenberge P. Total and specific lgE in nasal polyps is related to local eosinophilic inflammation. J Allergy Clin Immunol 2001; 107:607-14.

3. Bernstin JM. Nasal Polyp Diseases of the sinuses, Diagnosis and management. Kennedy, Bolger, Zinreich. London: BC Decker; 2001

4. Setsuko M, Nakamura $H$. Inflammatory cells in nasal mucosa and nasal polyps. Auris Nasus Larynx 2000; 27: 59-64.

5. Liu CM, Shun CT, Hsu MM. Lymphocyte subsets and antigenspecific IgE antibody in nasal polyps. Ann Allergy. 1994; 72(1):19-24

6. Fokkens WJ, Holm AF, Rijntjes E, Mulder PG, Vroom TM. Characterization and quantification of cellular infiltrates in nasal mucosa of patients with grass pollen allergy, non-allergic patients with nasal polyps and controls. Int Arch Allergy Appl Immunol. 1990; 93(1):66-72

7. Bellioni P, Ruscito P, Bevilacqua P, Maurizi M, Larocca LM, Maggiano N, Capelli A. Recent advances concerning etiopathogenesis of nasal polyposis. Acta Otorhinolaryngol Ital. $1989 ; 9(1): 3-13$

8. Conley DB, Tripathi A, Seiberling KA, Schleimer RP, Suh LA, Harris K,Paniagua MC, Grammer LC, Kern RC. Superantigens and chronic rhinosinusitis: skewing of T-cell receptor $\mathrm{V}$ beta-distributions in polyp-derived CD4+ and CD8+ T cells. Am J Rhinol. 2006; 20(5):534-9.

9. Hao J, Pang YT, Wang DY. Diffuse mucosal inflammation in nasal polyps and adjacent middle turbinate. Otolaryngol Head Neck Surg. 2006; 134(2):267-75

10. Verbruggen K, Van Cauwenberge P, Bachert C. Anti-lgE for the treatment of allergic rhinitis--and eventually nasal polyps? IntArchAllergy Immunol. 2009; 148(2):87-98.

11. Gevaert P, Holtappels G, Johansson SG. Organization of secondary lymphoid tissue and local $\operatorname{lgE}$ formation to staphylococcus aureus entrotoxins in nasal polyp tissue. Allergy 2005; 60: 71-9.

12. 12.Conley DB, TripathiA, Ditto AM. Chronic sinusitis with nasal polyps: Staphylococcal exotoxin immunoglobulin $\mathrm{E}$ and cellular inflammation. Am J Rhinol 2004 ;18: 273-8.

13. Suh YJ, Yoon SH, Sampson AP, Kim HJ. Specific immunoglobulin $E$ for staphylococcus entrotoxins in nasal polyps from patients with aspirin- intolerant asthma. Clin Exp Allergy 2004; 34: 1270-5. 
14. Pastorello EA, Incorvaia C, Riario-Sforza GG. Importance of allergic etiology in nasal polyposis. Allergy 1994;15:151-5.

15. Bernstein JM, Ballow M, Rich G. Lymphocyte subpopulations and cytokines in nasal polyps: is there a local immune system in the nasal polyp? Otolaryngol Head and neck Surg 2004; 130: 526-35.
16. Ihan A, Suskovic S. Flow cytometric analysis of lymphocytes isolated from nasal polyps. Folia Biol 1997;43: 15-8.

17. He L, Shi J, Xu G. The T-lymphocytes subsets expression in the human recurrent nasal polyps. Lin Chuang Er Bi Yan Hou Ke Za Zhi 2004;18: 97-9.

18. Muluk NB, Atasoy P. Localization of T cells and subtypes in the paranasal sinus and turbinate mucosa in patients with chronic sinusitis. J Otolarryngol 2004;33:235-42 